MAREK HENDRYKOWSKI

Instytut Filmu, Mediów i Sztuk Audiowizualnych Uniwersytet im. Adama Mickiewicza w Poznaniu

\title{
Na białym szlaku. Zapomniany film o wojnie
}

\begin{abstract}
AвsTract. Hendrykowski Marek, Na białym szlaku. Zapomniany film o wojnie ["On the White Trails”: a forgotten film about the war]. „Images” vol. XXVI, no 35. Poznań 2019. Adam Mickiewicz University Press. Pp. 103-115. ISSN 1731-450X. DOI 10.14746/i.2019.35.05.

The article is an analytical and interpretative study of behind-the-scenes aspects and the poetics of a little-known feature film titled On the White Trails, directed by Jarosław Brzozowski and Andrzej Wróbel.
\end{abstract}

KeYworDs: Jarosław Brzozowski, Andrzej Wróbel, film poetics, World War II drama, tough guys movie, genre, narration, Polish cinema, practice of film production

Nakręcony w latach 1960-1962 przez duet realizatorów Jarosław Brzozowski i Andrzej Wróbel fabularny dramat wojenny pod tytułem Na białym szlaku stanowi interesujący, choć mocno dziś zapomniany fragment historii polskiego kina lat sześćdziesiątych. Nawet wytrawni znawcy naszego filmu powojennego $\mathrm{z}$ trudem przypominają sobie dzisiaj o jego istnieniu. Warto po ponad pół wieku od premiery powrócić do niego - nie po to jednak, by starać się udowodnić, iż jest zapoznanym arcydziełem rodzimej kinematografii, bo byłaby to zwykła nieprawda, lecz po to, by wypełnić lukę zbiorowej pamięci.

W obecnej chwili okazuje się ona tak wielka, że w niedawno opublikowanym monograficznym opracowaniu Piotra Zwierzchowskiego dotyczącym historii tematyki wojennej w kinematografii PRL dekady lat sześćdziesiątych[1] tytuł ten wprawdzie jest marginalnie wzmiankowany, jako jeden z przykładów nieudanych produkcji tamtego okresu, ale twórca filmu, Jarosław Brzozowski, figuruje w tekście głównym i w indeksach tytułów filmowych oraz nazwisk pod imieniem Janusz (sic!). Tak więc, nie ma specjalnej przesady w stwierdzeniu, iż $\mathrm{Na}$ białym szlaku rzeczywiście zasługuje dzisiaj na miano zapomnianego filmu o wojnie.

O kulisach decyzji nakręcenia Na białym szlaku wiadomo niezbyt wiele. Spróbujmy zrekonstruować informacje i fakty. Pomysł narodził się z opowieści o dzielnym polskim traperze, którą pisarz usłyszał ponoć w czasie rejsu statkiem do norweskiego portu Tromsö. Jej tłem historycznym była sensacyjna historia tajnych hitlerowskich baz po-
Images vol. XXVI/no. 35

Poznań 2019

ISSN 1731-450X

[1] P. Zwierzchowski, Kino nowej pamięci. Obraz

II wojny światowej w kinie polskim lat 6o., Bydgoszcz

2013, s. 18, 333 i 339 .

Kulisy powstania 
larnych zakładanych pod nosem aliantów podczas II wojny światowej. Prace scenariuszowe nad filmem ruszyły w roku 1958. Z tego roku pochodzi złożona jako propozycja Zespołu „Studio” w Zespole do spraw Produkcji Filmowej Naczelnego Zarządu Kinematografii z datą 1 lipca 1958 pierwsza wersja scenariusza[2].

Autorzy, Alina i Czesław Centkiewiczowie, dokonali adaptacji własnej powieści pod tym samym tytułem. Najpierw powstała 52-stronicowa nowela, a następnie 77-stronicowy scenariusz. Efekt pracy obojga pisarzy zyskał aprobatę Komisji Ocen Scenariuszy. Z inicjatywy Jarosława Brzozowskiego projekt trafił uprzednio do Zespołu Autorów Filmowych „Studio”, którym kierowali: Aleksander Ford jako lider artystyczny, Henryk Hubert jako kierownik literacki (zastąpił na tym stanowisku w roku 1960 poprzedniego kierownika literackiego Romana Bratnego) oraz Zygmunt Król jako doświadczony szef produkcji.

Wybór Zespołu Filmowego „Studio” ze strony Centkiewiczów i Brzozowskiego był, jak się zdaje, podyktowany względami czysto pragmatycznymi. Produkcja fabularnego filmu, którego akcja dzieje się głównie w lodach Arktyki, wydawała się niewykonalna, a w każdym razie bardzo kosztowna. „Kadr”, „Iluzjon”, „Kamera” i inne zespoły filmowe nie okazały zainteresowania tym nieszablonowym projektem. Z powodu wielomiesięcznych pobytów Brzozowskiego na Spitsbergenie, gdzie kręcił dokumenty polarne, rozmowy z kierownictwem „Studia” mocno się przeciągały, ale ostateczna decyzja o umieszczeniu Na białym szlaku w planach produkcyjnych Zespołu zapadła na przełomie zimy i wiosny 1960 (notabene zanim powstała druga wersja scenariusza, o której mowa w przypisie 2).

W chwili realizacji Na białym szlaku Jarosław Brzozowski przekroczył pięćdziesiątkę. Dojrzały filmowiec, powszechnie kojarzony $\mathrm{z}$ ambitną twórczością $\mathrm{w}$ dziedzinie dokumentu (Wieliczka, Wielki redyk, Warszawa 56), a także filmu o sztuce (W pracowniach plastyków, Warszawa w malarstwie Canaletta, Tadeusz Kulisiewicz, Piotr Michałowski, Zbigniew Pronaszko) zamierzał spróbować sił w filmie fabularnym. W tamtych czasach przejście „na stronę” fabuły nie było u nas, nawet dla kogoś tak renomowanego i bardzo wysoko cenionego w swoim środowisku jak Jarosław Brzozowski, sprawą łatwą. Realizator

[2] Maszynopis powielony, dodajmy dla dochowania filmograficznej ścisłości, iż w dwu nieco różniących się od siebie wersjach, znajduje się w zbiorach Archiwum Filmoteki Narodowej - Instytutu Audiowizualnegopod sygn. S-1859 i S-2325. Istnieje również inna wersja scenariusza autorstwa Aliny i Czesława Centkiewiczów z grudnia 1960 (sygnatura S-4569). We wszystkich trzech literackich wersjach opowieści Polak Sikora i Niemiec Weber zostają odnalezieni i uratowani.

[3] Gwoli dochowania faktograficznej ścisłości należy dodać, iż kilkanaście lat wcześniej Jarosław Brzozowski nosił się z zamiarem nakręcenia pełnometrażowe- go filmu fabularnego. Rzecz nosiła tytuł Szałas w górach, należąc gatunkowo pospołu do filmów górskich oraz partyzanckich dramatów wojennych (historia osaczonego oddziału). Scenariusz napisał Brzozowski wspólnie z Aleksandrem Ciesielskim w styczniu 1947 roku. Przedsiębiorstwo Państwowe Film Polski po otrzymaniu negatywnych opinii Adama Ważyka i Kazimierza Sumerskiego projekt odrzuciło. Rok później (10 grudnia 1947) reżyser złożył kolejny kilkunastostronicowy projekt, tym razem narciarskiej humoreski wczasowej, zatytułowany Dziuś w górach. I w tym przypadku projekt został odrzucony. 
z wieloletnim dorobkiem twórczym, ogromnie doświadczony na polu dokumentalistyki, w fabule aktorskiej stawał się nowicjuszem i jako debiutant na tym polu zaczynał praktycznie wszystko od nowa[3].

Pół biedy, gdyby w grę wchodziła, dajmy na to, błaha komedia, melodramat albo baśń kostiumowa. Ryzyko ewentualnej porażki wydawało się w takim przypadku o wiele mniejsze. Owszem, tylko że $\mathrm{Na}$ białym szlaku żadną miarą nie należało do projektów tuzinkowych, ani tym bardziej produkcji łatwych, banalnych i rutynowych. Wprost przeciwnie, jako zadanie produkcyjne było przedsięwzięciem trudnym do realizacji. Mowa tu przede wszystkim o mroźnej, wichrowo-lodowej scenerii i nietypowych, ekstremalnie trudnych warunkach realizacji zdjęć, zwłaszcza scen aktorskich.

Podobnie wymagającemu dla całej ekipy zadaniu mógł podołać jedynie ktoś doskonale obeznany z filmowaniem w krajobrazie Arktyki. A takim kimś, dysponującym wyjątkowym kapitałem niezbędnego wtajemniczenia realizacyjnego, unikatowym wówczas w naszym kraju, był wtedy jeden tylko filmowiec: Jarosław Brzozowski.

$\mathrm{Na}$ białym szlaku podpisał tandem reżyserski: Jarosław Brzozowski i Andrzej Wróbel. Ten drugi, nieporównanie mniej doświadczony pod względem warsztatowym od znacznie starszego kolegi, stał się w najlepszym tego słowa znaczeniu drugim reżyserem. W latach 1952-1957 Wróbel studiował reżyserię w Państwowej Wyższej Szkole Filmowej w Łodzi. Tematy „zimowe” pociągały go już podczas studiów reżyserskich, czego dowodem jest dokumentalno-instruktażowa etiuda szkolna Skok narciarski (1955). Po studiach w Łodzi wszedł natychmiast do zawodu i jako asystent reżysera i II reżyser współpracował na planie z najlepszymi, między innymi: $\mathrm{z}$ Andrzejem Munkiem przy Eroice i Zezowatym szczęściu, z Andrzejem Wajdą przy Popiele i diamencie oraz z Witoldem Lesiewiczem przy dramacie wojennym Rok pierwszy.

Licząca siedem osób ekipa filmowa Brzozowskiego wyruszyła w podróż morską z Gdyni na Spitsbergen w ostatniej dekadzie czerwca 1960 roku. Produkcja Zespołu „Studio” została zatem zatwierdzona do realizacji, a filmowcy przystąpili do pracy, zanim pojawiła się niesławna uchwała Sekretariatu Komitetu Centralnego PZPR, o której będzie jeszcze mowa, dotycząca zasadniczych zmian programowych i wymogów ideologicznych narzuconych produkcji filmowej. Warto podkreślić ten chronologiczny fakt[4], bowiem powzięty znacznie wcześniej przez twórców zamysł realizacji nie był w tym akurat przypadku podyktowany oportunizmem ani koniunkturalnym podporządkowaniem się wymogom wynikającym ze zmiany politycznego kursu. Zrodził się on wcześniej w wyniku porozumienia między reżyserem a parą scenarzystów.

[4] Data premiery Na białym szlaku, która miała miejsce niemal trzy lata później, 15 marca 1963 w Warszawie, może wprowadzać w błąd w zestawieniu filmu Brzozowskiego i Wróbla z szeregiem innych tytułów tamtego okresu, „słusznych” i całkowicie już podporządkowanych linii ideologicznej partyjnego kierownictwa. 
Jeśli mowa o tematyce trudów życia na Dalekiej Północy i jej znajomości w powojennej Polsce, niezwykle popularny duet Centkiewiczów przez lata odgrywał rolę jej niezrównanego propagatora. Liczne wyprawy, długa lista wydawanych w wielkich nakładach poczytnych książek popularnonaukowych o Arktyce i Antarktydzie oraz setki spotkań i wieczorów autorskich z czytelnikami w całym kraju - wszystko to sprawiło, iż odległe światy fiordów, lodowców i zórz polarnych stały się z biegiem lat czymś dobrze znanym i przyswojonym zbiorowej wyobraźni. Ogromna w tym zasługa małżeńskiej pary pisarskiej Aliny i Czesława Centkiewiczów: autorów pierwowzoru literackiego oraz scenariusza.

Powieść Na białym szlaku, mająca do chwili obecnej wiele wydań, została po raz pierwszy opublikowana nakładem wydawnictwa Nasza Księgarnia w roku 1956. Ze względu na poczytność jej ekranizacja niosła $\mathrm{z}$ sobą niemałą szansę osiągnięcia frekwencyjnego sukcesu. Dodajmy, iż w niedługim odstępie czasu przed premierą filmu Na białym szlaku rok po roku ukazały się cztery inne książki Centkiewiczów: najpierw poszerzone wydanie przedwojennej opowieści reporterskiej Wyspy mgiet i wichrów (1959), następnie Opowieści spod bieguna (1960) i Kierunek Antarktyda (1961) oraz Fridtjöf, co z ciebie wyrośnie (1962) - zbeletryzowana biografia słynnego norweskiego biologa, oceanografa i badacza polarnego, laureata Pokojowej Nagrody Nobla, Fridtjöfa Nansena.

Kilka dodatkowych informacji o autorach. Swoją całożyciową przygodę z Daleką Północą zaczynał Czesław Centkiewicz (1904-1996) na długo przed wojną jako inżynier elektryk i fizyk. Studia inżynierskie odbył na politechnikach w Grenoble i w Liège. W latach przedwojennych pracował naukowo w Polskim Instytucie Meteorologicznym w Warszawie. Cykl ponad osiemdziesięciu wypraw polarnych rozpoczął w roku 1932 od kierownictwa (w wieku zaledwie dwudziestu ośmiu lat) ekspedycji na Wyspę Niedźwiedzią. W ponad sześćdziesięciu kolejnych towarzyszyła mu żona, Alina Centkiewiczowa (1907-1993).

Książki podróżnicze i przygodowe, które wspólnie napisali, czytała niegdyś cała Polska. Wydawane w pięciocyfrowych nakładach i często wznawiane, można je było bez trudu znaleźć w każdej bibliotece. Niektóre tytuły (Anaruk - chłopiec z Grenlandii, Odarpi, syn Egigwy) znalazły się w spisie lektur szkolnych przeznaczonych dla uczniów starszych klas szkół podstawowych. Podejmowane w tamtym okresie polskie wyprawy naukowo-badawcze na Spitsbergen, między innymi z okazji Międzynarodowego Roku Geofizycznego, dodatkowo nadały temu doniosły walor.

Utwory Centkiewiczów łączyły w sobie walory powieści przygodowej z gruntowną wiedzą o trudach życia na Dalekiej Północy. Charakterystyczny temat i motyw przewodni tych opowieści stanowi pełna przygód i niebezpieczeństw wędrówka odważnych śmiałków, pokonujących w skrajnie niesprzyjających i trudnych warunkach lodowy bezkres. „Taka wędrówka, którą podejmują ludzie - powiedziała w jednym z wywiadów Alina Centkiewiczowa - to zawsze wielka pró- 
ba charakterów, tam odpada wszystko, co słabe.” Trzeba przyznać, iż dramatyzm okoliczności i trudów, z którymi zmagają się bohaterowie, stanowi mocną stronę zarówno pierwowzoru, jak i filmu $\mathrm{Na}$ białym szlaku. Punktem wyjścia stała się dlań właśnie literacka opowieść Aliny i Czesława Centkiewiczów.

Świat Arktyki znali oboje doskonale, opisali jego realia i bohaterów krainy lodów w wielu książkach. Nie oni pierwsi, o czym warto pamiętać. Literatura, a po niej film eksploatowały tę tematykę na wiele różnych sposobów i przy wielu okazjach. Przychodzą na myśl klasyczne powieści i opowiadania autorstwa mistrzów opowieści o życiu na Dalekiej Północy: Jamesa Olivera Curwooda (Dolina ludzi milczących, Najdziksze serca) oraz Johna Griffitha Chaneya, czyli Jacka Londona (Za zdrowie wędrowca na szlaku, Biała cisza, Odyseja Pótnocy i inne opowiadania, a wśród nich zwłaszcza Love of Life oraz słynne arcydzieło małej formy literackiej, nowela Nieoczekiwane: opowieść o dzielnym policjancie z kanadyjskiej Królewskiej Konnej, który eskortuje schwytanego przestępcę.

Charakterystyczny dla tamtych, cieszących się na całym świecie ogromną poczytnością, utworów schemat fabularny, a zwłaszcza zaczerpnięty z noweli Londona Nieoczekiwane motyw morderczych trudów wędrówki przez śnieżny bezkres mężczyzn, pozostających z sobą w konflikcie i zmuszonych do solidarnej współpracy, by móc przeżyć, został przez dwoje polskich autorów przejęty i twórczo przetworzony na potrzeby: powieści, scenariusza i filmu.

Trafnie odnotował ten atut w swojej recenzji na łamach dziennika „Życie Warszawy” Stanisław Grzelecki, pisząc między innymi:

Sytuacja zagrożenia i niepewności życia, rozwijając się, przesłania, odsuwa na margines mechanizm pierwotnych przyczyn konfliktu. Napięcie wrogości słabnie pod naciskiem rzeczywistości, aż w końcu są już tylko dwaj ludzie zagubieni śród śnieżnych bezdroży, jednakowo zagrożeni śmiercią z zimna i wyczerpania, jednakowo spragnieni ciepłej strawy, wypoczynku, ochrony przed lodowatym wiatrem[5].

Po przybyciu na Spitsbergen ekipa Brzozowskiego rozbiła obóz w pobliżu fiordu Horsund, opodal lodowca Hansa, gdzie miały być kręcone zdjęcia. Niewielką bazę filmowców stanowiło zaledwie osiem namiotów. Praca była ciężka i wyczerpująca fizycznie - relacjonował w swej korespondencji dla tygodnika „Film” członek ekipy, doświadczony taternik i polarnik Jan Staszel[6]. Kręcenie odbywało się w skrajnie niesprzyjających warunkach: pośród sztormów, wichrów, mgieł i uporczywych opadów atmosferycznych, z nielicznymi „oknami” dobrej pogody. W sumie nakręcono około czterech tysięcy metrów materiału. Od początku założono, że za Kołem Polarnym zostaną zrealizowane tylko same plenery, bez udziału aktorów. Ci mieli się dopiero pojawić

[5] S. Grzelecki, Mróz kończy wszystko, „Życie Warszawy" 1963, nr 65.
[6] J. Staszel, Reportaż spod Bieguna, „Film” 1960, nr 36. 
na planie zdjęciowym w Polsce. W rolach ich dublerów oraz statystów wystąpili ubrani w odpowiednie stroje członkowie zespołu realizatorów.

$\mathrm{Na}$ realizację tak trudnego filmu mógł się odważyć tylko ktoś bardzo doświadczony. W połowie roku 1960 kinematografia polska nie dysponowała jeszcze, wykorzystywanym już przez filmowców na Zachodzie, lekkim mobilnym sprzętem dostosowanym do potrzeb zdjęć wykonywanych w tak ekstremalnych warunkach, jakie panują w Arktyce. Trzeba było posługiwać się więcej niż skromną, przestarzałą aparaturą zdjęciową, którą dysponowała wówczas baza techniczna naszych wytwórni. A to oznaczało ciągłą prowizorkę i ryzyko wielkiej improwizacji na planie, połączonej z chroniczną obawą, że coś absolutnie niezbędnego w trakcie pracy nagle odmówi realizatorom posłuszeństwa. Jednym słowem, mimowolny, lecz konieczny powrót do pionierskich czasów Flaherty’ego przy kręceniu Nanuka $z$ Pólnocy. Czerwcowa wyprawa Brzozowskiego w roku 1960 na Spitsbergen była trzecią ekspedycją polarną $\mathrm{w}$ jego życiu. $\mathrm{Z}$ dwóch poprzednich przywiózł kilka osobiście nakręconych niezwykłej urody filmowej dokumentów przyrodniczo-naukowych. Teraz jednak w grę wchodziło coś nieporównanie trudniejszego i bardziej wymagającego: pełnometrażowy fabularny film aktorski. Brzozowski był wytrawnym operatorem, co bardzo usprawniło realizację zarówno na Spitsbergenie, jak w Polsce. Jego wieloletnie filmowe doświadczenie pomogło rozwiązać wiele kłopotów.

Realizatorzy od początku stanęli przed zasadniczym problemem logistycznym. Była nim niemożność osobistej obecności aktorów na planie. Szkopuł w tym, że wykonawcy głównych ról, Leon Niemczyk i Emil Karewicz ze względu na swoje rozliczne zobowiązania zawodowe musieli pozostać na miejscu w kraju i nie mogli brać udziału w wielomiesięcznej wyprawie za Koło Polarne. Nie można było liczyć na kręcenie zdjęć $\mathrm{z}$ nimi w autentycznych podbiegunowych sceneriach.

Istna kwadratura koła: aktorski film bez możliwości udziału wykonawców w zdjęciach. Brzozowski znalazł jednak wyjście z tej trudnej sytuacji. Z góry założył, że wszystkie sceny aktorskie zostaną nakręcone w Polsce i wytypował do tego celu jedyne miejsce, którego surowa przyroda do złudzenia przypominała lodowcowy krajobraz, a mianowicie okolice wysokogórskiego schroniska w Dolinie Pięciu Stawów. Zdjęcia w Polsce sfilmowano po powrocie ze Spitsbergenu, na przełomie grudnia i stycznia, choć i tutaj pojawiły się całkiem nieoczekiwane trudności...

Sam Jarosław Brzozowski mówił w wywiadzie dla tygodnika „Film”[7], że była to niemal druga wyprawa polarna, a warunki zdjęciowe zimą wysoko w Tatrach skomentował następująco:

[7] J. Brzozowski, Od Bieguna do Doliny Pięciu Stawów. Rozmawiała Elżbieta Smoleń-Wasilewska, „Film” 1960, nr 51. 
Szalone trudności związane z transportem sprzętu - a jest to niemały majdan, wózki, kamery - tam, gdzie właściwie wszystko wnosi się na plecach, zorganizowanie odpowiedniego zaopatrzenia dla sporej ekipy, wskazuje, iż jest to przedsięwzięcie niemałe. Liczymy na znaczną pomoc helikoptera. W naszym bagażu znajdować się będzie m.in. kilka silników samolotowych, które przy niełaskawych warunkach atmosferycznych będą „robiły” zamieć[8].

Któż mógł przewidzieć, że tamtego roku zima w Tatrach przebiegnie tak łagodnie i bezśnieżnie. Zdjęcia $\mathrm{z}$ tego powodu przerwano, a ich realizację ukończono dopiero zimą następnego roku. Ostatecznie jednak efekt ekranowy okazał się bardzo przekonywający, a iluzja tożsamości miejsca akcji zupełna. Prawdę mówiąc, nie była to bynajmniej operatorska gra w ciemno. Aby mieć pewność co do identycznego rezultatu na taśmie, autor filmu najpierw wykonał w Pięciu Stawach i na Spitsbergenie zdjęcia próbne. Określenie „pierwszy polski film polarny” w zestawieniu $\mathrm{z}$ tym, co na ekranie, nie wydaje się nic a nic przesadzone.

Wojenne realia rozgrywającego się na Dalekiej Północy konfliktu ukazanego w filmie $\mathrm{Na}$ białym szlaku nie były czymś od początku do końca wymyślonym na potrzeby fikcji literackiej. Autor scenariusza Czesław Centkiewicz komentował je na łamach krakowskiego tygodnika „Życie Literackie” następująco:

Oparłem się na prawdziwym wydarzeniu. Zmagania wojenne nie ominęły Arktyki, gdzie obie strony zakładały swe bazy meteorologiczne, prowadząc jednocześnie utarczki patroli i bombardowania z powietrza. W opowiadaniu chciałem pokazać, jak zmienia się psychika wrogów w warunkach polarnych, wobec największego nieprzyjaciela człowieka, jakim jest bezlitosna przyroda arktyczna. W obliczu tego niebezpieczeństwa nienawiść musi zejść na dalszy plan, a do głosu dochodzi zwyczajna ludzka solidarność[9].

Do tematu tego powrócimy jeszcze w toku dalszych rozważań.

Wydawać by się mogło, że mający swoją premierę wczesną wiosną 1963 debiut fabularny Brzozowskiego i Wróbla stanowi ewenement jedyny w swoim rodzaju na gruncie polskiego kina. Że nie sposób go połączyć i skojarzyć z niczym innym, gdyż bardzo odstaje - zarówno tematycznie, jak i pod względem formy i gatunku - od poetyki innych filmów tamtej doby. Tak jednak nie jest. Wprost przeciwnie. Odmienny charakter Na białym szlaku zawiera w sobie rysy dające się wpisać w to, czym żyło i czym było wówczas rodzime kino artystyczne i popularne. Pod warunkiem, że nie będziemy go na siłę kojarzyć i łączyć z filmami takimi, jak: Samson, Nóż w wodzie, Zaduszki, Jak być kochaną, Tarpany czy Rękopis znaleziony w Saragossie.

W wielokrotnie opisanym przez historyków polskiego kina zwrocie poszukiwań tematycznych naszych filmowców, które przypadają mniej więcej na lata 1960-1964, istotne znaczenie ma - odgórnie

[8] Ibidem.

[9] Przedpremierowa wypowiedź Czesława Centkiewicza ukazała się pod tytułem $\mathrm{Na}$ białym szlaku
Kontekst historycznofilmowy w notce prasowej na łamach „Życia Literackiego” 1963 nr 11. 
narzucony i wymuszony dyrektywami Uchwały Sekretariatu KC PZPR z czerwca 1960 roku - kurs polityczny obrany na kino popularne. Zabieg mecenasa był prosty: dość dramatów i gorzkich obrachunków, orientujemy się w stronę masowego odbiorcy. W intencji ideologicznej najwyższych władz realizacja tego typu filmów miała stanowić popierany przez partię odwrót od polskiej szkoły filmowej[10].

Jak się wkrótce okazało, zarządzanie środkami na produkcję poprzez utrącanie projektów z różnych względów „niewygodnych” dla decydentów doprowadziło do przejściowej reorientacji twórców. W rezultacie w produkcji i na ekranach kin zagościły niebawem tytuły sensacyjne, przygodowe, batalistyczne, komediowe, kostiumowe, kabaretowe, a poważna problematyka $\mathrm{w}$ filmie, $\mathrm{z}$ niewielkimi wyjątkami, została na dłuższy czas usunięta w cień. Oszałamiający sukces frekwencyjny Krzyżaków zrobił swoje. Szeroka kinowa widownia uznała generalnie owo dążenie za coś pozytywnego.

$\mathrm{W}$ repertuarowej magmie pojawiły się, $\mathrm{z}$ roku na rok coraz liczniejsze rodzime produkcje o charakterze rozrywkowym, skrojone pod masowy gust. Twórczość reprezentująca wyższego lotu aspiracje twórców i będąca wyzwaniem dla widza stanęła wówczas pod wielkim znakiem zapytania ze względu na dezaprobatę partii. Na białym szlaku okazuje się w tym kontekście przykładem symptomatycznego rozdwojenia dążeń, które mają pogodzić format problemowy filmu z niezbędnym pakietem ekranowych atrakcji. W tym przypadku $74 \mathrm{mi-}$ nuty projekcji wypełnia kino popularne $\mathrm{z}$ niekoniecznie popularnym przesłaniem.

Recepcja krytyczna

Recenzje i omówienia filmu Na białym szlaku ukazały się na łamach bardzo wielu gazet: od „Trybuny Ludu”, „Żołnierza Wolności” i „Walki Młodych”, poprzez „Życie Warszawy”, „Expres Wieczorny”, „Sztandar Młodych”, „Kurier Polski”, do „Słowa Powszechnego”. Szeroko odnotowała go prasa regionalna: „Dziennik Bałtycki”, „Głos Wybrzeża”, łódzki „Głos Robotniczy”, wrocławskie "Słowo Polskie” i „Gazeta Robotnicza”, krakowski „Dziennik Polski”, „Gazeta Krakowska”, „Trybuna Opolska”, „Trybuna Mazowiecka”, „Głos Szczeciński”, „Nowiny Rzeszowskie”, bydgoska "Gazeta Pomorska”, poznańska „Gazeta Chłopska”, „Głos Wielkopolski”, kieleckie „Słowo Ludu”, „Kurier Lubelski”, lubelski "Sztandar Ludu” i inne. Sporo miejsca i uwagi poświęciły mu też na swoich łamach czasopisma nie tylko branżowe (czyli tygodniki „Film” i „Ekran”), ale również: „Życie Literackie”, „Stolica”, „Tygodnik Kulturalny”, „Świat”, „Dookoła Świata”, „Światowid”, „Tygodnik Demokratyczny”, „Panorama Północy”, „7 Dni w Polsce”, „Zwierciadło”.

Jak widać, sporo tego: parędziesiąt recenzji i notek recenzenckich publikowanych jak Polska długa i szeroka w gazetach i tygodnikach o zasięgu zarówno ogólnopolskim, jak regionalnym. Owszem, tylko że

[10] M. Hendrykowski, Jak likwidowano polska szkołe filmowa, „Kwartalnik Filmowy” 2018, nr 103-104. 
ilość omówień, które się wówczas ukazały, nie przechodzi w jakość. Kiedy wczytać się w to, co na ogół pisano o Na białym szlaku i na co głównie zwracano uwagę, uderza powierzchowność i schematyzm odczytań. Generalny ton opinii był, z pewnymi wyjątkami, w miarę pozytywny, choć raczej wstrzemięźliwy. W dostrzeżonych i poruszanych szczegółach natomiast, na które powoływali się piszący, większość recenzji odzwierciedla dezorientację i swoistą merytoryczną bezradność osądu.

Autor Na białym szlaku nie uprawia natrętnej propagandy, próbuje iść własną drogą, unikając czarno-białych podziałów i schematów. Prowadzi narrację w taki sposób, by skłonić widza do refleksji nad bezsensem wojny: tej i każdej innej. Presja stereotypu złego (bądź niemądrego i tępego) Niemca w obligatoryjnym zestawieniu z dobrym, szlachetnym i mądrym Polakiem była tak duża, że odejście od niego nie zostało zauważone. Bezradność recenzentów i powierzchowność spojrzenia widać bardzo wyraźnie w najczęściej chybionych interpretacjach przesłania. Żaden z ówczesnych komentatorów (także tych publikujących w pismach branżowych) nie spróbował odczytać wymowy tej opowieści „na własną rękę”, odbiegając od banalnych klisz recenzenckiego szablonu. Nieporadność tych odczytań dotyczy zwłaszcza wymowy całości i rozpoznania gatunku, do którego film się odwołuje.

Jarosław Brzozowski był zbyt doświadczonym filmowcem, by nie wiedzieć, że atrakcyjność przedstawienia tej historii przesądzi o sukcesie $\mathrm{w}$ kinach i u widza. Stąd dobrze pomyślany pakiet ekranowych atrakcji: aktorzy z górnej półki, dwa mocne, nieustępliwe charaktery, zażarty pojedynek pary antagonistów-twardzieli, nagłe zwroty akcji, czeluść lodowca, pojedynek z białym niedźwiedziem, walka o życie z wieczną zimą, pożerającą wszystko, co stara się przeżyć i przetrwać. $\mathrm{Z}$ pewnością dobrze byłoby pozbyć się kilku całkiem zbędnych, rezonerskich kwestii dialogowych, ale te wydają się dzisiaj koniecznym serwitutem poniesionym przez autora na rzecz strażników ideologicznej poprawności.

Ważniejsze wydaje się co innego, a mianowicie kwestia gatunku filmu. Na białym szlaku nie jest pod względem genologicznym utworem jednorodnym, zawiera $\mathrm{w}$ sobie amalgamat kilku różnych gatunków: dramatu wojennego, filmu sensacyjnego, tzw. tough guys story (opowieści o mocnych ludziach). Nie jest jednak żadnym z nich do końca. Wprawdzie to film o toczącej się wojnie, którego akcja dzieje się w końcu kwietnia i na początku maja 1945 roku. A przecież nie sama wojna jest jego głównym tematem. Jeśli już, to jest nim wrogość i to wrogość przezwyciężona („Zamiast dwóch wrogów - szło teraz dwu ludzi", czytamy pod koniec noweli Centkiewiczów[11]).

Matryce odczytania utworu filmowego mogą w pewnych przypadkach w istotny sposób przeinaczyć jego rzeczywiste przesłanie, wy-

[11] A. i Cz. Centkiewiczowie, Na białym szlaku (nowelka). Maszynopis powielony w zbiorach Archiwum
Filmoteki Narodowej - Instytutu Audiowizualnego, sygn. S-12444, s. 50. 
nikające z projektu semantycznej konstrukcji całości. Do przypadków tych należy między innymi omawiany film. Czy recenzenci rzeczywiście odczytali prawidłowo jego przesłanie?

Szczególnie wiele zastrzeżeń zebrało zakończenie $\mathrm{Na}$ białym szlaku. Niektórzy z krytyków wytaczali przeciwko scenie finałowej ciężkie działa. Sugerowali też, czy wręcz otwarcie wmawiali jej tendencyjne znaczenie, którego wcale nie zawierała. Nasuwa się w tym miejscu zasadne pytanie: dlaczego tak się stało? Co takiego sprawiło, że na łamach prasy pojawiły się opaczne odczytania i rozmaite pretensje zgłaszane pod adresem twórców filmu? Otóż prawdopodobna przyczyna tych powierzchownych interpretacji, z niefortunnymi nadinterpretacjami włącznie, tkwi w niezdolności do odszukania sensu głębszego niż ten, który mylnie zasugerują autorzy recenzji.

Recenzencka tuba, z jaką mamy tu do czynienia, odtwarza i powiela sposób myślenia władzy o twórczości filmowej i podejście do niej. Zabrakło w filmie jednoznacznej konkluzji. Wszelkie dwuznaczności są czymś niepożądanym (rodzajem „błędu” ideowego), a wieloznaczność dzieła zostaje potępiona jako niewybaczalna wada i słabość. W jakiejś mierze uwadze piszących umknęła formuła i ogólna koncepcja $\mathrm{Na}$ białym szlaku, choć przecież nie była ona czymś nieczytelnym.

Autorzy pierwowzoru literackiego, scenariusza i scenopisu założyli sobie stworzenie opowieści o Północy w typie Londonowskim, tyle że z udziałem bohaterów w mundurach i w realiach z II wojny światowej. Wersja ekranowa od początku do końca respektuje to koncepcyjne założenie. Ambicje twórcze zarówno Centkiewiczów, jak i Brozowskiego sięgają znacznie dalej niż sensacyjno-przygodowa opowieść o walkach na Dalekiej Północy rodem z broszurowej serii z Tygrysem. Mówił o tym wyraźnie Czesław Centkiewicz w przywołanym wyżej wywiadzie udzielonym jeszcze przed premierą.

$\mathrm{Na}$ przykładzie recepcji krytycznej $\mathrm{Na}$ białym szlaku widać jak na dłoni, iż rzeczywisty kłopot i problem z kinem popularnym w PRL nie polegał wcale na braku tematów czy niedostatku umiejętności filmowców, lecz na wymogu bezalternatywnie uproszczonej ideologizacji wszelkich elementów danego przekazu. Nie poziom warsztatowy okazywał się ważny w ocenie (choć na posiedzeniach komisji kolaudacyjnych często stanowił „dyżurny” argument zastępczy, używany przez obie strony: zarówno w obronie filmu, jak i w przypadku stawianych zarzutów). Najważniejszym kryterium oceny było co innego, a mianowicie mgliście pojęte „zaangażowanie” twórcy i „wymowa” jego dzieła.

Zawartość ideowa utworu: słuszna (czytaj: akceptowana przez strażników linii partii) lub niesłuszna (ostrożnie kwestionowana bądź też bezpardonowo przez nich atakowana) stanowiła poligon podobnych manewrów, a częstokroć teren (nie tylko kolaudacyjnej) batalii o film i wokół niego. Postrzegane przez taki pryzmat „sztuka” i „artyzm” Z wielkim trudem broniły się przed presją jedynie słusznej ideologii, nierzadko padając ofiarą ingerencji cenzorskich. Na białym szlaku, 
podobnie jak dziesiątki innych produkcji tamtego okresu, również podlegało takiej ideologicznej kontroli.

Spróbujmy całkowicie oderwać się od powyższego trybu myślenia i schematycznej oceny filmu, odkrywając po latach nie to, co akceptowane przez ówczesną władzę, lecz to, co atrakcyjne i wartościowe dla widza. Pierwszą z zalet, natychmiast dostrzegalną, jest oryginalny temat opowieści: wojna światowa tocząca się w realiach Dalekiej Północy. Na polskich ekranach był już wówczas wyświetlany francusko-norweski dramat wojenny Bitwa o ciężkq wodę (reż. Jean Dréville, Titus Vibe-Müller, 1947). Ale w filmie polskim wraz z Na białym szlaku istotnie pojawiło się coś nowego.

Wartość drugą, dostrzeżoną przez niewielu recenzentów, stanowił niezwykły doprawdy wysiłek aktorski obu wykonawców: Emila Karewicza (rocznik 1923) i młodszego odeń o pół roku Leona Niemczyka. Obaj dobiegali już wtedy czterdziestki, stąd trzeba docenić ich ogromne poświęcenie na planie zdjęciowym podczas mroźnej i śnieżnej zimy w Dolinie Pięciu Stawów. Skądinąd wiadomo, że przed rozpoczęciem zdjęć z własnej woli przeszli intensywny wysokogórski trening i zaprawę wytrzymałościową, aby zaprezentować na ekranie odpowiednią sprawność.

Kolejną niewątpliwą zaletą $\mathrm{Na}$ białym szlaku jest obraz psychofizycznej udręki i trudów egzystencji (nie sposób tu mówić o życiu w normalnych warunkach) na skraju wojennej cywilizacji. Tam, gdzie się ona kończy (doszczętne spalenie bazy, brak łączności, mordercze serie z hitlerowskich peemów, ostatnich kilkanaście zapałek, sanie z ekwipunkiem wpadające w szczelinę lodowca, brak pożywienia, polowanie na mewę, walka z polarnym niedźwiedziem), zaczyna się lodowe piekło i iście pierwotna walka o przetrwanie.

Trzeba przyznać, że ten motyw zyskał w Na białym szlaku bardzo sugestywny wyraz. Poetyka zdjęć Jarosława Brzozowskiego i Bogusława Lambacha w niektórych ujęciach - zarówno w planach ogólnych, jak i w kapitalnych zbliżeniach postaci (sceny potężnej zamieci) - osiąga unikatowy rodzaj wrażeń i przeżyć: budzących nawet dzisiaj zaskoczenie widza.

Najważniejszą zaletą $\mathrm{Na}$ białym szlaku jest jednak zaskakujące przesłanie filmu, rozpatrywane w ścisłym powiązaniu $z$ jego gatunkiem. Warto zauważyć, iż został nakręcony w czasach zimnej wojny i wzmożonej aktywności dążących do konfrontacji mocarstw (kryzys kubański, budowa muru na granicy NRD etc.). Zimna wojna (ze szczególnym podkreśleniem Niemiec Zachodnich Adenauera) oznacza wymóg ukazywania wroga w określony sposób. Portrety Niemców w polskim filmie są wiec w tym okresie bezwarunkowo negatywne i odrażające. To wizerunkowy standard, który Brzozowski respektuje, ale nie do końca...

Sama znajomość filmu w jego ekranowym kształcie pozwala wyrobić sobie sąd o końcowym efekcie. Oprócz tego istnieje coś jeszcze, a mianowicie twórcze dążenie do jego osiągnięcia. Nie sposób twierdzić, że autorzy noweli i kolejnych wersji scenariusza dostarczyli coś, co znalazło swoje pełne odzwierciedlenie na ekranie. Otwarte zakończenie, 
które znamy z filmu, nie pojawia się w żadnej z literackich wersji $\mathrm{Na}$ białym szlaku. Nie ma go także, co ciekawe, w scenopisie sporządzonym przez Jarosława Brzozowskiego i Krzysztofa Gruszczyńskiego w roku 1962[12]. Ostatnie ujęcie filmu wygląda w nim tak: „Sikora: - Czy oni się kiedyś zmienią?... Sikora i Hagerup idą w stronę fiordu. Przed nimi rytmicznym krokiem idą Niemcy. Z tyłu eskortują ich żołnierze $\mathrm{z}$ bronią gotową do strzału. KONIEC".

Lektura wszystkich tych materiałów skłania do wniosku, że zakończenie, które znamy z ekranu, nie pojawiło się od razu. Jest ono rezultatem ciągu dążeń, z których żadne nie wykrystalizowało się w dostatecznym stopniu dopóty, dopóki Jarosław Brzozowski nie odnalazł go osobiście w trakcie realizacji. Mamy tu do czynienia z poszukiwaniem drogi wyjścia (mowa o możliwie najbardziej nośnym zakończeniu), które reżyser metodą prób i błędów odkrył dopiero w wyniku wielu kolejnych prób. Każda z omawianych przez nas wersji (nowela, kolejne wersje scenariusza, scenopis) zakładała w różnych konfiguracjach zdarzeń akcji, że Sikora i Weber zostaną odnalezieni. A jednak żadna $\mathrm{z}$ nich nie pojawia się w końcu na ekranie.

Startując od zaprezentowania owego „dyżurnego" stereotypu złego Niemca, dodajmy ogrywanego w filmie dość ostentacyjnie (między innymi Hakenkreuz oberleutnanta Webera za kampanię polską) przez pierwszą część Na białym szlaku, Brzozowski coraz bardziej odchodzi od tej konwencji. Opowiedziana przez niego wojenna historia spod Bieguna komplikuje się i niesie z sobą zgoła przeciwną wymowę. Jej mocno zaakcentowane zakończenie sugeruje dead end (w stylu Ceny strachu Henri-Georges'a Clouzota), ale równie dobrze może zostać odczytane inaczej i uznane przez widza za otwarte.

Otwarte w tym sensie, iż zachowuje niezbędną dozę wieloznaczności. To musiało wywołać konfuzję u rutynowo myślących recenzentów. Powstał rzadki w tamtych czasach film antywojenny. Polski cywil Sikora i niemiecki oficer Weber stają się w świetle takiego odczytania postaciami emblematycznymi. Śmiertelni wrogowie, Niemiec i Polak, których organiczna (Wrzesień 1939, okupacja, masowe zbrodnie, wyrządzone krzywdy, barbarzyństwo w niewyobrażalnej skali, eksterminacja) wrogość zamienia się na naszych oczach w solidarną współpracę i walkę o życie.

No T A

F I L M O G R A F I C Z N A
Na białym szlaku

Scenariusz: Alina Centkiewicz, Czesław Centkiewicz na podstawie własnej powieści pod tym samym tytułem Dialogi: Alina Centkiewicz, Czesław Centiewicz, Krzysztof Gruszczyński Reżyseria: Jarosław Brzozowski, Andrzej Wróbel

Zdjęcia: Bogusław Lambach

[12] J. Brozowski, K. Gruszczyński, Na białym szlaku.

Scenopis, Warszawa 1962, stron 167. 
Asystenci operatora: Andrzej J. Jaroszewicz, Zbigniew Kociuba

Operator kamery: Jerzy Bielak

Współpraca operatorska: Stanisław Mazurkiewicz, Jerzy Białek

Scenografia: Jan Grandys

Kostiumy: Jerzy Kondracki, współpraca kostiumograficzna: Maria Kobierska

Muzyka: Kazimierz Serocki, w wykonaniu Orkiestry Filharmonii Narodowej w Warszawie pod dyrekcją Arnolda Rezlera

Montaż: Mirosława Garlicka, współpraca: Aurelia Rut

Charakteryzacja: Roman Kęsikowski, Lidia Łopatowska

Kierownictwo produkcji: Marceli Nowak

II kierownik produkcji: Józef Drzewicki

Asystenci produkcji: Zofia Budzińska, Ryszard Barski

Wykonawcy: Leon Niemczyk (Sikora, członek załogi stacji arktycznej 330); Emil Karewicz (oberleutnant Weber); Bożena Kurowska (oficer brytyjski WAF); Jerzy Antczak (pułkownik duński), Edward Dobrzański (Fritz); Ryszard Kotys (meteorolog stacji 330); Jerzy Krasowski (Hans); Witold Pyrkosz (feldfebel); Ferdynand Matysik (żołnierz niemiecki); Barbara Połomska (oficer brytyjski WAF); Stanisław Michalik (porucznik dowodzący ekspedycją poszukiwawczą); Robert Rogulski (Eskimos Kari, członek stacji arktycznej 330); Witold Skaruch (oficer brytyjski); Kazimierz Talarczyk (Olaf Peterson); Ludwik Ziemblic (radiotelegrafista Nils); Kazimierz Wilamowski (oficer brytyjski); Mariusz Gorczyński (żołnierz niemiecki); Leopold Rene Nowak (żołnierz niemiecki); Józef Zbiróg (żołnierz niemiecki), oraz Orest Czabak (dublujący Leona Niemczyka), Maciej Zalewski (dublujący Emila Karewicza), Stefan Batanowicz (dubler Eskimosa) i inni

Lektor: Jan Suzin

Film czarnobiały

Długość: $2112 \mathrm{~m}$

Czas projekcji: 74 minuty

Produkcja: Zespół Realizatorów Filmowych „Studio”

Premiera odbyła się 15 marca 1963 w Warszawie

Braun A., Na białym szlaku, „Zwierciadło” 1963, nr 14

Brzozowski J., Od Bieguna do Doliny Pięciu Stawów. Rozmawiała Elżbieta Smoleń-Wasilewska, „Film” 1960 nr 51

Eljasiak J., Druga wojna światowa za kręgiem polarnym, „Sztandar Młodych” 1963, nr 65

Giżycki J., Grenlandzka przygoda z morałem, „Film” 1963, nr 12

Grzelecki S., Mróz kończy wszystko, „Życie Warszawy” 1963, nr 65

Hendrykowski M., Jak likwidowano polska szkołe filmowa, ,Kwartalnik Filmowy” 2018, nr 103-104

Jaszcz (Jan Alfred Szczepański), I śniegi bywają różne, „Trybuna Ludu” 1963, nr 77

Kochański K., Na szlaku przygody, „Tygodnik Kulturalny” 1963, nr 13

Michalski Cz., Na białym szlaku, „Światowid” 1963, nr 14

Michalski Cz., Na białym szlaku, „Walka Młodych” 1963, nr 12

Staszel J., Reportaż spod Bieguna, „Film” 1960, nr 36

Toeplitz K.T., Dwa filmy polskie, „Świat” 1963, nr 13

Zwierzchowski P., Kino nowej pamięci. Obraz II wojny światowej w kinie polskim lat 60., Bydgoszcz 2013 